\title{
A study on employability skills among college students in Coimbatore district, Tamil Nadu
}

\author{
G. Gowsalya, R. Preetha
}

${ }^{1}$ Assistant Professor, Department of Management, VLB Janakiammal College of Arts and Science, Coimbatore, Tamil

Nadu, India, ${ }^{2}$ Assistant Professor and Head, Department of Management, VLB Janakiammal College of Arts and Science, Coimbatore, Tamil Nadu, India

\section{AbSTraCT}

Purpose: India has a lot of workforce resources. The present-day youth is qualified enough to make use of wide scope of opportunities open before them. However, they need to shape themselves to get into such jobs by acquiring soft skills. This paper is an attempt to emphasize the necessity of employability skills. It also highlights the objectives of soft skills and various teaching methodologies to be applied. Methodology: The population used for this study was college students in Coimbatore district. Accordingly, a total sample size of 100 college students was used for analysis. Despite their year of course difference, the population can be considered as homogenous in one aspect. This study was solely based on the primary data obtained from the respondents through semi-structured questionnaire that constitutes questions about basic personal information, communication, listing, learning, basic literacy and numeracy, teamwork skill, problem-solving, creativity, computer skill, leadership skill, organization thinking skill, work ethics, management skill, and self-management skill, the factor analysis is performed to group these statements on priority basis. The respondents filled the questionnaires by themselves due to ease of understanding and familiarity with filling questionnaires in their bureaus. The survey for this study was conducted from January to March 2021 at Coimbatore district. Findings: The multiple regression analysis results revealed that independent factors such as listening skills, learning skills, logical skills, time management skills, creativity, computer skills, organizing thinking skills, teamwork skills, problem-solving skills, work ethics, leadership skills, management skills, and selfmanagement skills are all positively influenced by employability skills. Implications: The study implies that the college should organize ongoing training and workshop programs to familiarize students with the current needs and market expectations of various industries. Originality: In previous research was carried out in employability skills, very limited research has been carried out in the area of this study.

Key words: Cronbach alpha, Employability skill, Graduate employee ranking multiple regression analysis, Indian skill report 2020

\section{INTRODUCTION}

The most significant obstacle to India's progress and future is a lack of competent workers in all industries. According to the Indian skill survey, men and women have similar employability scores. Telangana, Rajasthan, and Delhi have a strong female talent pool. Maharashtra is the most employable state, followed by Tamil Nadu, Uttar Pradesh, Andhra Pradesh, and Karnataka. In terms of the most employable cities, Mumbai ranks first followed by Hyderabad.

\section{*Corresponding Author:}

Dr. R. Preetha, Department of Management, VLB Janakiammal College of Arts and Science, Coimbatore, Tamil Nadu, India. E-mail: gowsalyanamakkal@gmail.com

Received: 22 July, 2021; Accepted: 15 September, 2021

DOI: $10.18843 / \mathrm{ijcms} / \mathrm{v} 12 \mathrm{i} 3 / 02$ 
Gowsalya and Preetha: A Study on employability skills among college students in Coimbatore district, Tamil Nadu

According to the table 1, India talent report 2019-2020, $46.21 \%$ of students were either employable or ready to take up employment in 2019 , compared to $33 \%$ in 2014 and $47.38 \%$ in 2018.

The table 2 shows that in the year 2020, Massachusetts Institute of Technology is rated first, Stanford University is ranked second, University of California is ranked third, University of Sydney is ranked fourth, and Harvard University is ranked fifth, as shown in Table 2. In India, one institution, the Indian Institute of Technology, has been identified, and it has gone up one position from 111 in the year 2020 .

\section{Review of Literature}

Fajaryati et al. (2020)., the goal of this study was to determine the employers' required employability abilities in the chosen area, as well as how to incorporate them into the educational process. In this study, a review of the literature revealed that employability skills, such as communication, teamwork, problem-solving, and technical abilities, are required in connection to future job needs, as determined by employers. According to the study, the best way to include employability skills into the teaching process is to incorporate them into all topics in the classroom.

Chowdhury and Miah (2019), employers and students have very different perspectives on the abilities needed

\begin{tabular}{lc}
\multicolumn{2}{c}{ Table 1: Indian skill report 2020} \\
Year & Employability percentage \\
\hline $2019-2020$ & 46.12 \\
$2018-2019$ & 47.38 \\
$2017-2018$ & 45.60 \\
$2016-2017$ & 40.44 \\
\hline
\end{tabular}

Source: (Indian skill Report 2020)

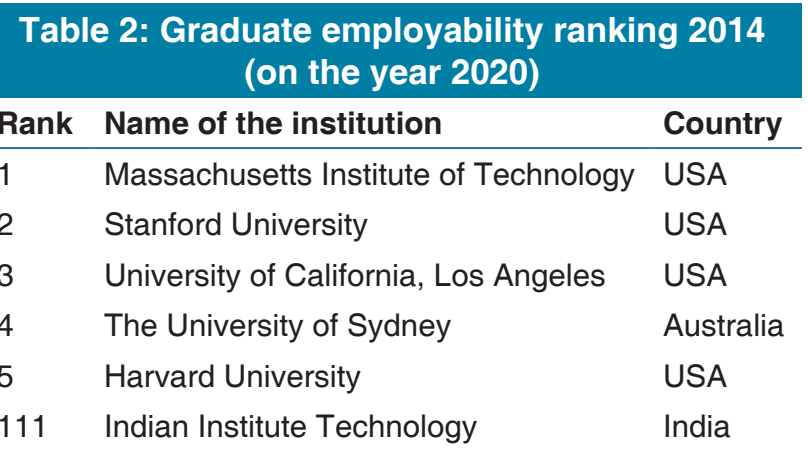

Source: (www.qschina.cn) for entry-level marketing and sales jobs, according to the survey. Managers ranked abilities such as planning, organization, experience, professionalism, main courses studied, and a good attitude toward work of importance. Students, on the other hand, emphasized abilities such as organizational commitment, work area dedication, sophisticated problem-solving skills, internship in a relevant sector, critical thinking capacity, and fundamental understanding of marketing.

Fraser et al. (2019), the study aims that knowing how well higher education providers prepare learners for the working world is becoming increasingly important at all program levels, and this is nowhere more apparent than with vocational education training. The study suggests that the key takeaway of this research is raised awareness and intentionality of the overt and covert approaches vocational educators are using to enhance the employability of their students.

Subbu and Rajeshkaran (2018), based on a review of numerous researches related to employability skills, the study found that the employability skill required at workplaces, the employability framework, the struggles adopted to improve employability skills, and the employer's opinion of employability skills.

Gowsalya and Elavarasan (2018), the aim of the study was to the employability skill for present-day graduates, to study graduates self-perceived level of competence at performing employability skill, and to suggest a way to improve their employability skill along with their programs. The study concluded that the Indian educational governance is the one which is in earnest need of improving. Further that, instructors should practice employability skill during teaching and learning session so that it could assist students to understand ways of applying the skills by themselves.

Vanitha and Jaganathan (2018), the purpose of this study was to identify the employability skills that employers perceive to be important for entry-level graduates and the skills set required for sustainable employability of graduates in India. The study suggests that the employability skills are very essential in the current global job market. Skill shortage remains one of the major constraints to continued growth of the Indian economy.

Bassou and Jason (2016), the study's goal was to see how employers and university professors of human resource development (HRD) and management viewed employability abilities for entry-level graduate positions. As a consequence of this study, kinds of employability 
skills that are prevalent among HRD program instructors and employers in the United States and worldwide may be recognized. One-way analysis of variance (ANOVA) was used to determine the interrelationships between the variables of interest among employees and faculty members in the United States and globally. There is a substantial link between 16 of the 18 factors studied and the kind of respondents, with the exception of communication skills and technology use, according to the research.

\section{Statement of the Problem}

This increasing gap between what is taught and what is needed to improve employability must be addressed. There are many job openings, but the issue is the disparity between the quality of higher education and the labor market's demands. As a result, both supply and demand side variables, which are frequently beyond an individual's control, have an impact on employability. Higher education institutions may give subject matter knowledge, but they fall short of instilling in graduates the necessary skills to obtain, maintain, and grow in their careers. The purpose of this study is to uncover the underlying elements of employability skills in college students, keeping in mind the relevance of the idea. When the samples were randomly selected from the five different colleges in the district of Coimbatore, personal characteristics of college students were examined, and these variables are connected to each other in the study. (Table 3 )

\section{Objectives of the Study}

The objectives of the study were as follows:

1. To examine the demographic profile of college students in the Coimbatore district

2. To determine the degree of employable skills among college students

3. To record the recommendations regarding the enhancement of students toward employability skills.

\section{METHODOLOGY}

The research was conducted using both primary and secondary data. A semi-structured questionnaire was delivered physically, and a few questionnaires were sent to known respondents, to obtain primary data. The research was primarily descriptive in nature. According to the research, students from Coimbatore City College were chosen at random. The number of people that may participate was restricted to 100 (college students). For data

Table 3: Determinants of employability skills - multiple regression analysis

\begin{tabular}{|c|c|c|c|}
\hline Variables & Regression coefficient & Standard error & $t$ value \\
\hline Age & -0.0001 & 0.0002 & 0.2818 \\
\hline Gender & 0.0003 & 0.0003 & 0.1676 \\
\hline Nativity & 0.0002 & 0.0003 & 0.2649 \\
\hline Course of study & 0.0008 & 0.0003 & 0.0113 \\
\hline Communication skills & $0.0845^{\star *}$ & 0.0000 & 0.0000 \\
\hline Listening skills & $0.0564^{* *}$ & 0.0000 & 0.0000 \\
\hline Learning skills & $0.0563^{* *}$ & 0.0000 & 0.0000 \\
\hline Basic literacy and numerical skills & $0.0563^{\star *}$ & 0.0000 & 0.0000 \\
\hline Time management & $0.0704^{* *}$ & 0.0000 & 0.0000 \\
\hline Creativity & $0.0422^{\star *}$ & 0.0000 & 0.0000 \\
\hline Computer skills & $0.0986^{* *}$ & 0.0000 & 0.0000 \\
\hline Organization thinking skills & $0.0704^{\star *}$ & 0.0000 & 0.0000 \\
\hline Teamwork skills & $0.0564^{\star *}$ & 0.0000 & 0.0000 \\
\hline Problem-solving skills & $0.0845^{\star \star}$ & 0.0000 & 0.0000 \\
\hline Work ethics & $0.0422^{\star *}$ & 0.0000 & 0.0000 \\
\hline Leadership skills & $0.0845^{\star *}$ & 0.0000 & 0.0000 \\
\hline Management skills & $0.0564^{\star *}$ & 0.0000 & 0.0000 \\
\hline Self-management & $0.1408^{* *}$ & 0.0000 & 0.0000 \\
\hline
\end{tabular}

Source: (Collected and computed through the questionnaire). *Significant at five per cent level, ${ }^{* *}$ Significant at one per cent level 
collection, the researcher employed a questionnaire. For the data collection, the researcher utilized a standardized scale. The data were analyzed with the help of SPSS. The statistical tools used for the study are as follows:

- Percentage analysis

- Multiple regression.

\section{Cronbach Alpha Reliability}

Cronbach's alpha is a standard measure of dependability, and a Cronbach's alpha value of 0.70 is the customary requirement (Ogbonna, 2001).

The Cronbach's coefficient alpha should be larger than 0.6 to meet the overall requirements. All of the ideas were acceptable, and a total of 37 items were kept for the five constructs in the study, since all of the eight constructs had alpha values that met the requirements. (Table 4)

\section{Limitation of the Study}

The research was carried out among college students from several institutions in the Coimbatore district. The study is limited to a small sample size, which lowers the number of replies. The researcher encountered several challenges in obtaining clearance and distributing the questionnaire to students directly. However, through personal connection and relationships with teachers and students, the research was able to distribute the questionnaire.

\section{Analysis and Interpretation}

\section{Percentage analysis}

Table 5 shows that the bulk of the sample responses are between the ages of 18 and 20 years. Males made up 63\% of those who answered. With $66 \%$ of respondents from rural areas and 34\% from urban areas, the majority of the sample respondents chosen for the research are from rural areas. Arts students account for $42 \%$ of responses, engineering students for $32 \%$, and science students for $26 \%$.

\section{Multiple Regression Analysis}

Table 4: Cronbach's alpha of constructs reliability statistics

\begin{tabular}{lc} 
Cronbach's alpha & No. of items \\
\hline 0.915 & 37 \\
\hline Source: (Collected and computed through questionnaire)
\end{tabular}

Constant: -0.0015

Std. error of estimate: 0.0020

$\overline{\mathrm{R}}^{2}: 0.1000$

$\mathrm{R}^{2}: 0.1000^{* *}$

\section{Communication}

Communications have a favorable impact on employable skills, according to the regression coefficient. As a result, having good communication skills lead to decreased stress, more productivity, and improved relationship building techniques.

\section{Listening}

Effective communication necessitates the ability to listen. According to the regression coefficient, there is a favorably impact on employability skills.

\section{Learning}

Skill for learning is a collection of resources that may be used to help students acquire and teach academic skills. Learning skills have a favorable impact on employable abilities, according to the regression coefficient.

\section{Basic literacy and numerical skill}

To engage in and handle the mathematical demands of diverse circumstances, you must be able to obtain, apply, interpret, and convey mathematical knowledge and concepts. Basic literacy and numeracy abilities have a favorable effect on employability skills, according to the regression coefficient. Numeracy is considered as a vital employability skill as a result of more employees participating in increasingly complicated activities.

\section{Teamwork skill}

The regression coefficient shows that teamwork abilities have a favorable impact on employability. As a result, nearly every profession requires to operate as a part of team.

\section{Creativity}

According to the regression coefficient, creativity has a favorable impact on employable abilities.

\section{Computer skill}

According to the regression coefficient, computer abilities have a favorable effect on employable skills. As a result, having basic computer knowledge is highly necessary nowadays to get/do a work.

\section{Organization culture}




\begin{tabular}{lllcc} 
& & Table 5: Demographic profiles & \\
S. No. & Personal factor & Parameter & Frequency & Percentage \\
\hline 1 & Age & $18-20$ & 57 & 57 \\
& & $21-23$ & 43 & 43 \\
& & Total & 100 & 100 \\
2 & Male & 63 & 63 \\
& Gender & Female & 37 & 37 \\
& & Total & 100 & 100 \\
3 & Nativity & Rural & 34 & 34 \\
& & Total & 66 & 66 \\
& Course of study & Arts & 100 & 100 \\
4 & Science & 42 & 42 \\
& & Engineering & 26 & 26 \\
& & Total & 32 & 32 \\
& & & 100 & 100 \\
\hline
\end{tabular}

Source: (Collected and computed through questionnaire)

Employees can learn rapidly and solve issues, think creatively, and acquire and evaluate information meaningfully. The regression coefficient suggests that organizational culture has a favorable effect on employable skills. As a result, many of the highest-paying occupations involve critical thinking abilities, such as developing good ideas and making crucial judgments.

\section{Time management skill}

Life gets hectic, both within and outside of the office. Workload must be balanced and priorities must be established. According to the regression coefficient, time management skill has a favorable effect on employable skills. As a result, they must be completely self-sufficient in terms of managing their time and prioritizing actions.

\section{Problem-solving}

They will confront difficulties that will require them to describe a problem, create a suitable solution, and put it to good use. The regression coefficient suggests that problemsolving abilities have a favorable effect on employability skills.

\section{Work ethics}

Work ethics promotes a pleasant work environment. Employees acquire a sense of loyalty and commitment to the business as well. According to the regression coefficient, work ethics skills have a favorable effect on employability skills.

\section{Leadership skill}

According to the regression coefficient, leadership skills have a favorable effect on employable skills. The ability to exhibit leadership abilities when appropriate is highly recommended.

\section{Management skill}

According to the regression coefficient, management skill has a favorable effect on employable skills. As a result, knowing and demonstrating strong management abilities can assist to position oneself for a successful career.

\section{Self-management skill}

According to the regression coefficient, self-management abilities have a favorable effect on employable skills. As a result, accept responsibility for one's own actions, decisions, and outcomes.

\section{FINDINGS, SUGGESTION, AND CONCLUSION}

Listening skills, learning skills, logical skills, time management skills, creativity, computer skills, organizing thinking skills, team work skills, problem-solving skills, work ethics, leadership skills, management skills, and self-management skills are all positively influenced by employability skills, according to the regression coefficient.

The students indicated a favorable attitude toward peer 
evaluation, but they were concerned about their abilities to assess peers and the responsibility that came with it. Employers are concerned about the lack of employability skills displayed in entry level of job applications. The college should organize ongoing training and workshop programs to familiarize students with the current needs and market expectations of various industries. Most professors fail to motivate their ward because they are solely concerned with the examination.

\section{CONFLICTS OF INTERESTS}

There is no financial support and sponsorship for this research. There is no conflict of interest to declare.

\section{ACKNOWLEDGMENTS}

Acknowledgement is not applicable.

\section{REFERENCES}

Bassou, M., \& Jason, D. (2016). Employability skills as perceived by employers and university faculty in the fields of human resource development (HRD) for entry level graduate jobs. Journal of Human Resource and Sustainability Studies, 4, 39-49.

Chowdhury, T. A., \& Miah, M. K. (2019). Perceptions of students and employers regarding employability skills for entry-level positions in marketing and sales. Austrian Journal of Career Development, 25(2), 55-68.

Fajaryati, N., Budiyono, B., \& Wiranto, M. A. (2020). The employability skills needed to face the demands of work in the future: Systematic literature reviews. Open Engineering, 10(1), 595-603.

Fraser, C., Duignan, G., Stewart, D., \& Rodrigues, A. (2019). Overt and covert: Strategies for building employability skills of vocational education graduates. Journal of Teaching and Learning for Graduate Employability, 10(1), 157-172. 